\title{
4-D evolution of SE Asia's mantle from geological reconstructions and seismic tomography
}

\section{Anne Replumaz ${ }^{\mathrm{a}, *}$, Hrafnkell Kárason ${ }^{\mathrm{b}}$, Rob D. van der Hilst ${ }^{\mathrm{b}}$, Jean Besse $^{\mathrm{c}}$, Paul Tapponnier ${ }^{\mathrm{c}}$}

a Université C.B. Lyon 1, UMR CNRS 5570 Bât. géode, Laboratoire Dynamique de la Lithosphère, 2 rue R. Dubois,

69622 Villeurbanne Cedex, France

b Massachussets Institute of Technology, 77 Massachussets Av., Cambridge, MA 01239, USA

c Institut de Physique du Globe de Paris, 4 place Jussieu, 75005 Paris, France

Received 18 July 2003; received in revised form 20 January 2004; accepted 21 January 2004

\begin{abstract}
How the collision between India and Asia is related to processes deeper in the mantle is unclear. Here we compare geological reconstructions of block motions within Asia since $\approx 50$ Ma with the tomographically imaged threedimensional (3-D) morphology of subducted lithosphere to obtain insight into the spatiotemporal evolution of mantle structure. Past positions of the convergent margin show remarkable similarities with slab geometry at specific depths. The striking change in slab geometry from a linear structure beneath $1100 \mathrm{~km}$ to an increasingly distorted shape at depths of less than $700 \mathrm{~km}$ results from collision. The slab contours match the progressive deformation of Asia's margin, including India's indentation and Sundaland's extrusion. Ever since the onset of collision, the Indian plate appears to have overridden its own sinking mantle and it does not seem, at present, to underthrust Tibet significantly north of the Zangbo suture. If correct, this observation would provide further evidence against models of plateau build-up involving Indian lithosphere. The tomographic images beneath India confirm that Asian deformation has absorbed at least $\approx 1500 \mathrm{~km}$ of convergence since collision began. From the match between the southeastward motion of Sundaland between 40 and $20 \mathrm{Ma}$ and the principal change in slab structure between 700 and $1100 \mathrm{~km}$ depths, we infer that lateral advection in the mantle is small and that the sinking rate beneath Sunda was $\sim 2 \mathrm{~cm} / \mathrm{yr}$ in the lower mantle and $\sim 5 \mathrm{~cm} / \mathrm{yr}$ above the transition zone.
\end{abstract}

(C) 2004 Elsevier B.V. All rights reserved.

Keywords: India-Asia collision; mantle tomography block reconstruction; spatio-temporal evolution of mantle structure; matching tectonic and tomography

\section{Introduction}

In recent years, global, bodywave seismic tomography with routinely processed travel-time

* Corresponding author.

E-mail address: anne.replumaz@univ-lyon1.fr (A. Replumaz). data, for instance from the International Seismological Centre (ISC), has been particularly successful at mapping, in three dimensions, cold lith- 
ospheric material sinking into the mantle along and beneath the active margins of large plates. Many studies have focussed on whole mantle convection patterns, an objective well adapted to the global nature of the database. Fewer attempts have been made at imaging specific regions, with sizes smaller than $\approx 5000 \mathrm{~km}$, using fractions of the database, with notable exceptions in the Mediterranean (e.g., [1,2] ) and the western Pacific subduction zones (e.g., $[3,4])$. The continued accumulation of new data makes such regional studies increasingly more feasible, even away from the active seismic zones associated with subduction.

Along most convergent margins where oceanic plates subduct into the mantle, the upper plate deforms little, with the exception of accretion and marginal basin extension. Relating the dynamics of the subducting plate to tectonic shortening within the upper plate is then a second-order problem. This is not the case, however, for continental collision zones, where the crust of both plates is often observed to have shortened many hundreds of kilometers. In such regions, relating surface deformations to the dynamics of sinking lithospheric material is important, and the India/Asia collision zone is the most obvious candidate for trying to unravel this relationship. Because both our quantitative understanding of surface deformations and the accuracy of tomographic images improve as new chronological, structural, paleomagnetic, and seismic data accumulate, it has become feasible to integrate, at scales of only a few hundred kilometers, the deformations of Asia and India with the temporal evolution, past the onset of collision, of the major subduction zone that brought the two plates together.

Here we try to improve on previous work (e.g., $[5,6])$ by bringing face to face state of the art tomographic images of the mantle beneath southern Asia and reconstructed shapes of the Asian continent since the onset of collision, each obtained through completely independent approaches and with distinct data sets. The comparison strengthens previous inferences and provides new insight into the four-dimensional (4-D) evolution of the collision zone, the deformation of southeast Asia, and the tectonic growth of Tibet.

\section{Two-dimensional (2-D) reconstruction of the India/Asia convergent plate boundary from block tectonics, between $50 \mathrm{Ma}$ and the present}

Following the closure of the Mesozoic Tethys ocean, the India-Asia collision created - and continues to shape - the Himalayan range and the Tibet plateau. It also induced widespread strain in SE Asia and China. There is mounting evidence that a substantial part of the deformation of continents is localized on long and relatively narrow faults and shear zones (e.g., [7-9]). Many of these zones cut the base of the crust [10,11], and some extend to the base of the lithosphere (e.g., [12]). This makes it feasible to describe such deformation by motions of coherent lithospheric blocks separated by those faults. In Asia the large-scale Cenozoic fault pattern is well known. In many places, finite offsets of geological markers are now much better documented (e.g., [13-16]), and measurements of long-term (Holocene or Quaternary) slip rates are more reliable and numerous (e.g., $[17,18,45,52])$. Such data have become sufficient to retro-deform much of the area affected by the India-Asia collision using a block model on the sphere [19].

The block pattern is derived from fault traces obtained from integrative mapping based on detailed geomorphic and tectonic field studies and complemented by SPOT and LANDSAT image analysis and interpolation (e.g., [17,18,20-24]). The blocks are moved backward in time by steps of a few millions of years [19]. The timing of each step corresponds to main changes in the deformation regime during the collision, particularly on the large strike-slip faults of eastern Asia. Among such changes, we focus on those that have been well documented: the dextral reactivation of the Red River fault around $5 \mathrm{Ma}[13,14]$, the end of left-lateral motion along the Red River-Ailao Shan shear zone around $15 \mathrm{Ma}$ [25], the onset of seafloor spreading in the South China Sea around $30 \mathrm{Ma}$ [26], and the activation of the Wang Chao and three Pagodas faults around $40 \mathrm{Ma}$ [27].

For each retro-deformation step the blocks are first rotated on the sphere without shape change. The position of each block is adjusted to fit with 
the available data on offsets and/or slip rates along all of its boundary faults during the corresponding time span. The surface of certain blocks is then allowed to expand or shrink coherently along tectonic boundaries where the crust is known to shorten (thrusts) or extend (rifts). Remaining geometrical misfits are corrected by internal, distributed block bending (see [19] for more detail). Gaps and overlaps in the fit are thus removed, and the continuity of the block pattern restored in order to proceed with backward reconstruction. Finally, the fault pattern activated in the next time step is updated. The search for overall compatibility at the scale of the entire deformation zone is a key element of the approach. Solving for self-consistency between block motions over large areas shows that they are not in- dependent, which places first-order constraints on regions where little or no data are available. For instance, lateral motions of large 'distal' blocks such as Indochina, which are well constrained by seafloor spreading and paleomagnetism [28], provide key information on deformation in the central part of the collision zone.

The evolution scenario we obtain is based on a synthesis of tectonic evidence now available and will undoubtedly improve as the database expands. Nevertheless, however crude at this stage, it can be used to obtain a first-order reconstruction of the change in position and shape of the convergent boundary around southern Asia, all the way from the Himalayan collision front, in the northwest, to the outer limit of the Asian continent and the Pacific subduction zones, in

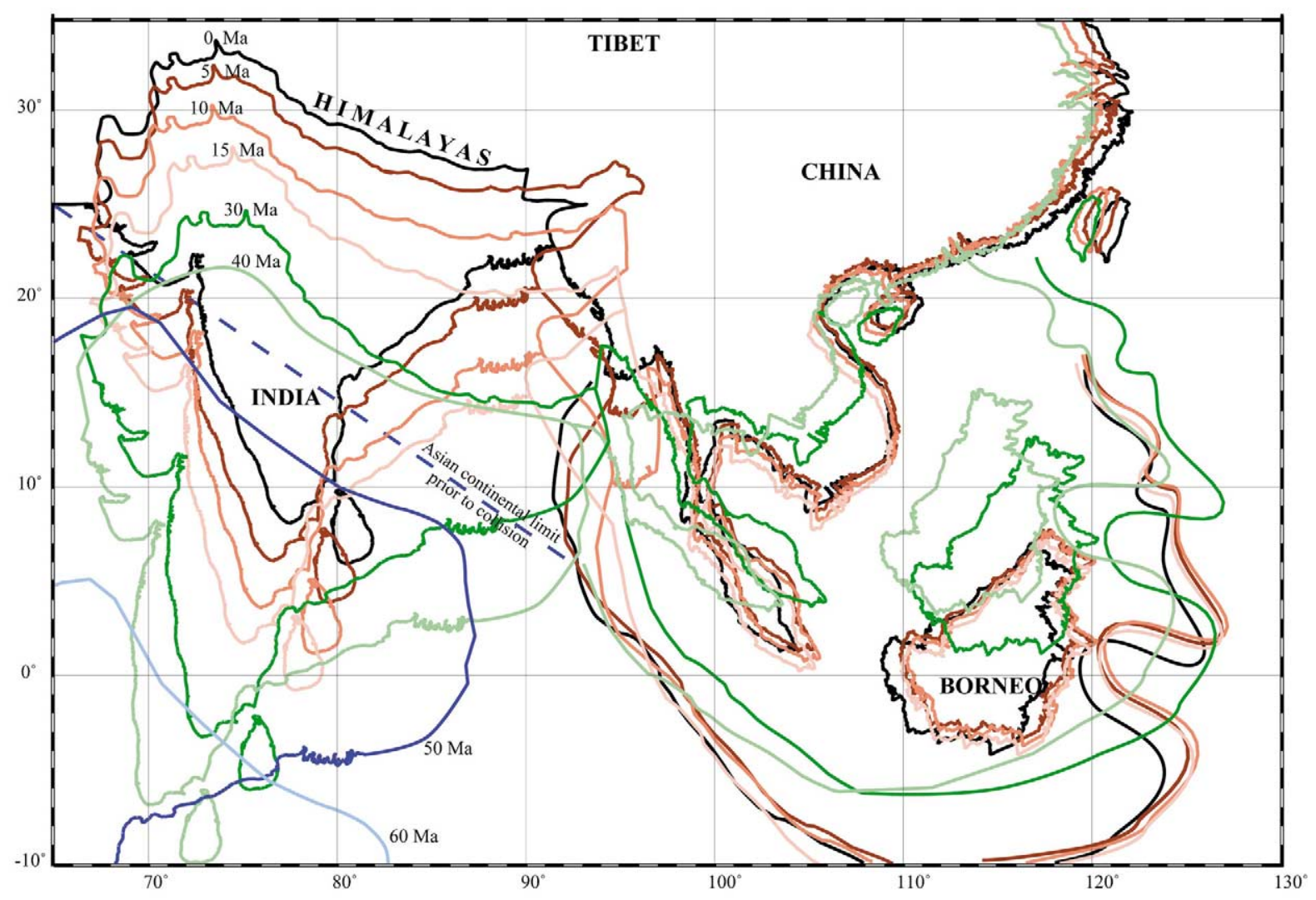

Fig. 1. Reconstructed positions of India and of southeast Asian blocks (with respect to stable Siberia) at 50, 40, 30, 15, 10 and 5 Ma (after [19]). 

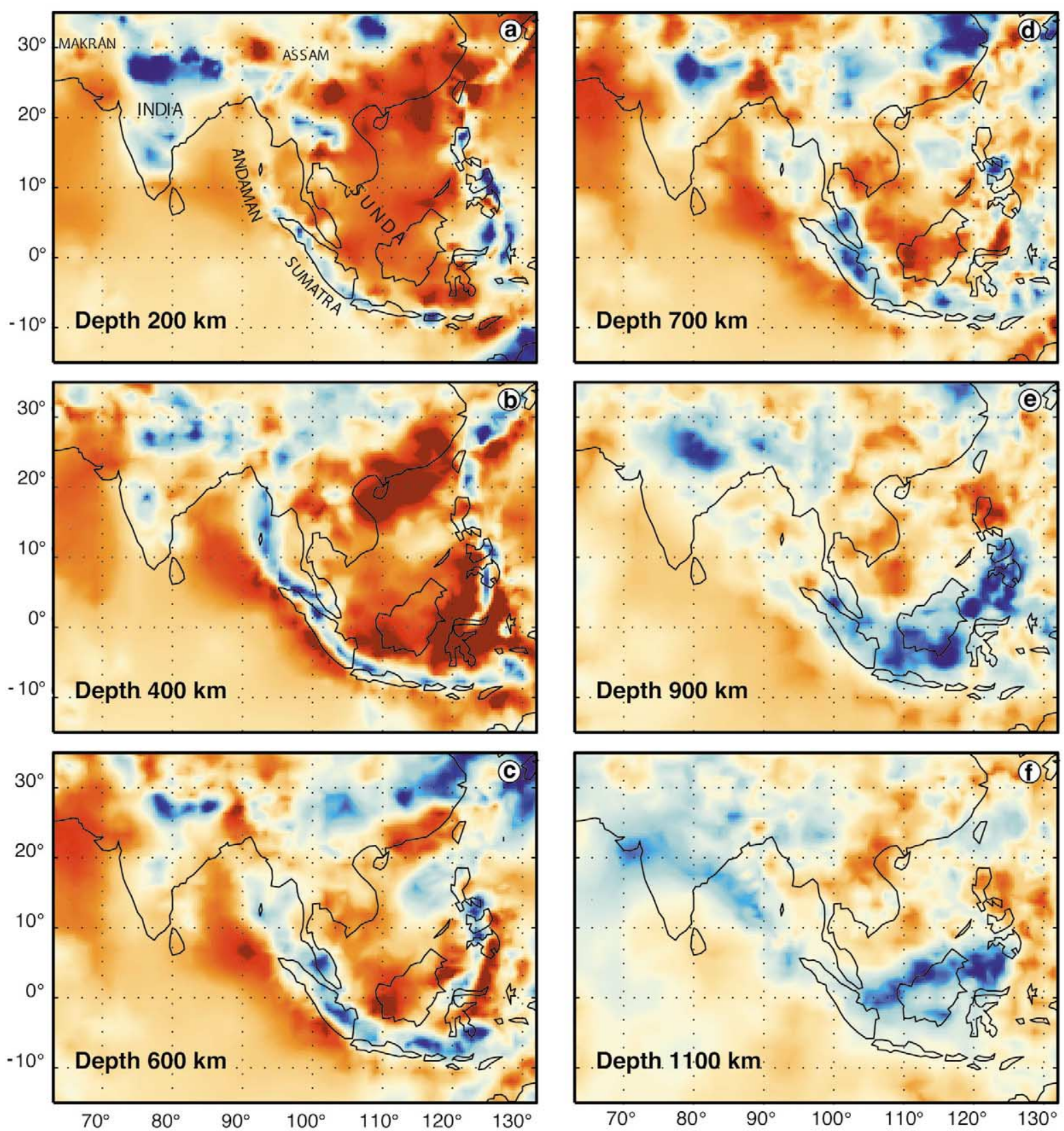

Slow
$(0.8 \%)$

Fast

$(+0.8 \%)$

Fig. 2. Horizontal, tomographic sections of mantle velocity structure beneath India and SE Asia at depths of 200, 400, 600, 700, 900, and $1100 \mathrm{~km}$ (from [31]). 
the southeast (Fig. 1). In turn, this 50-5 Ma reconstruction, in six stages, of past locations of the India-Asia and Australia-Asia convergent margins can be compared with tomographic maps of the mantle beneath SE Asia to investigate how plate boundary migration affects mantle flow trajectories and how fast subducted lithosphere sinks into Earth's mantle.

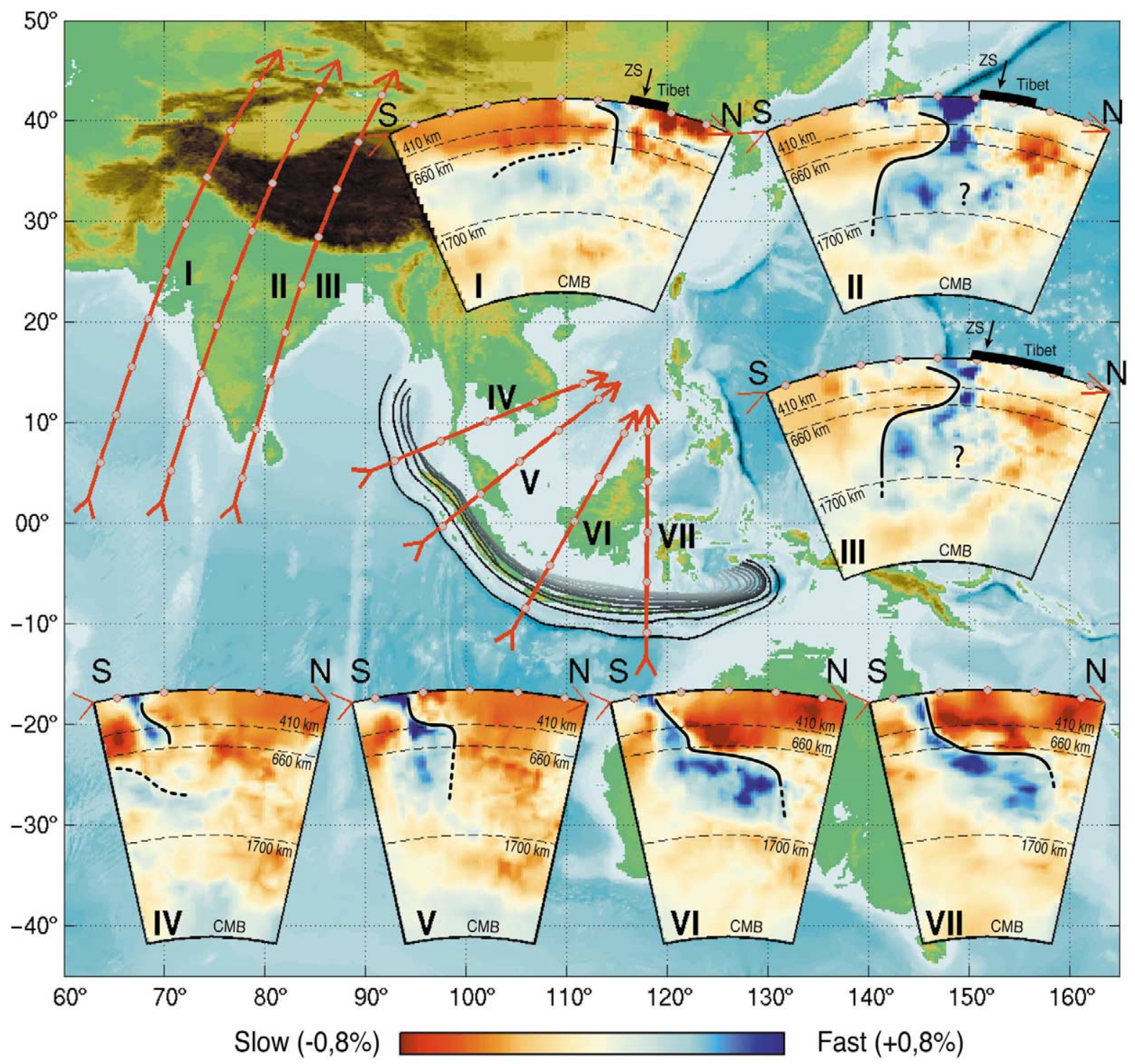

Fig. 3. Vertical sections of deep mantle structure beneath India/Asia plate boundary. From west to east: across Himalaya-Tibet (I, II, III), Andaman arc (IV), and Sunda arc (V, VI, VII). Most continuous linear edges of high-wavespeed anomalies corresponding to subducted lithosphere are contoured. Note that contours outline southern and northern edges of anomalies beneath India and Sunda, respectively, because anomalies' lower parts spread out below transition zone and subducted mantle lithosphere is overturned beneath India. On sections I, II, and III, thick black 'plate' and arrow indicate positions of Himalaya-Tibet highlands (elevation not to scale) and Zangbo suture (ZS), respectively. 


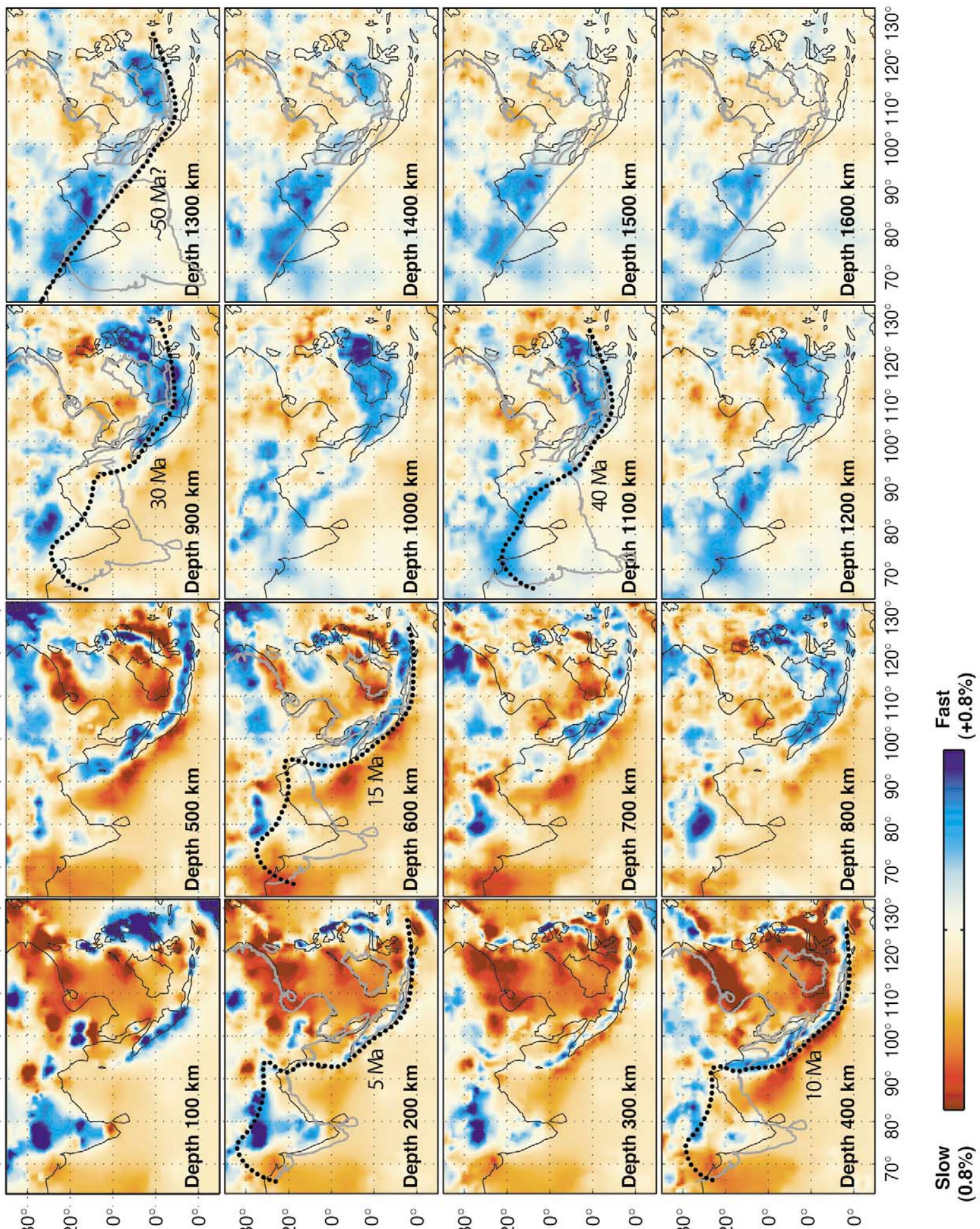




\section{3-D tomographic imaging of the mantle beneath southeast Asia}

The tomographic images used here (Figs. 2-5) are derived from a global inversion of travel-time residuals of $\sim 8 \times 10^{6}$ direct $P, \sim 0.6 \times 10^{6}$ depth phases $p P$, and almost $1 \times 10^{6}$ core refracted $P K P$ for subsets of almost 300000 earthquakes between $1 / 1 / 1964$ and 31/12/2000 [29], as well as smaller numbers of absolute and differential times of $P P-P, P K P-P_{\text {diff }}$, and $P K P$, measured accurately by waveform cross correlation from digital seismogram $[30,31]$. The model is parameterized with an irregular grid of constant wavespeed cells, the smallest being $0.5^{\circ} \times 0.5^{\circ}$, which allows detailed imaging in regions of dense data coverage, and 3-D sensitivity kernels are used to account for the difference in frequency of the data used. The latter allows low frequency data (e.g., $P P$ ) to constrain long wavelength structure while permitting the short-period data (e.g., $P$ ) to resolve smallscale heterogeneity. Map views (Figs. 2, 4 and 5) and vertical sections (Fig. 3) illustrate the 3-D morphology of subducted plate slabs beneath Indonesia and India.

Fig. 3 reveals that seismically fast slabs beneath Sunda and India plunge to at least $1500 \mathrm{~km}$ depth, which is well beyond the upper mantle transition zone. These structures form the central and easternmost parts of the deep mantle structure that has been interpreted as the remnant of subducted Tethys oceanic lithosphere [6,32,33]. In the shallowest mantle, parts of the back-arc regions (e.g., South China Sea, Sulu Sea, Fig. 2a, b) appear as seismically slow, and the Precambrian shields of India and Australia stand out as seismically fast (Fig. 2a), in accord with surface wave studies [34-36]. Resolution tests [31] indicate that the deep mantle structures discussed here are well within the resolution limit of the data used. The precise connection of these structures with India at shallow depth, however, cannot be estab- lished unambiguously with the data sets used by Kárason and Van der Hilst [30].

\section{Match between plate boundary position and mantle structure}

Since about $60 \mathrm{Ma}$ the movements of eastern Asia in the hotspot reference frame have been small (e.g., [37]. For the kinematic reconstructions (Fig. 1) and their comparison to 3-D mantle structure it is, therefore, legitimate (see also [6]) and simplest to use a reference frame steady with regard to present-day Siberia. We investigate the first-order, qualitative match between past plate boundary positions and mantle structure from deep (ancient) to shallow (recent).

At a depth of $1100 \mathrm{~km}$ (Fig. 2) and below (Fig. 4) the SW boundary of the NW-SE-trending high-wavespeed anomaly in the mantle stretches almost linearly from 75 to $105^{\circ} \mathrm{E}$. The position and shape of this boundary do not change much down to $1500 \mathrm{~km}$. In the present-day Siberian frame it connects in a simple, straight way central Sumatra to the Makran, across the southern tip of India. Most likely, it marks the locus of unabated Late Mesozoic subduction of oceanic lithosphere along what was probably the continuous, steady, and simple-shaped margin of Eurasia prior to collision. The geological reconstruction of Asia's margin at 50 or $55 \mathrm{Ma}$ (Fig. 1) provides a good match to the deep, high-wavespeed anomaly that marks the subducted slab (Fig. 4) if one allows for $400-1000 \mathrm{~km}$ of Indian shortening in the Himalayas, consistent with most structural and paleomagnetic studies (e.g., [38-40]). This match is also in agreement with the paleolatitudes of Cretaceous and early Tertiary rocks in southern Tibet (e.g., [41-43]).

Between 1100 and $700 \mathrm{~km}$ depth, the geometry of the high-wavespeed slab anomaly changes radically. East of India, at about $95^{\circ} \mathrm{E}$, it appears to

Fig. 4. Complete set of 16 horizontal sections of mantle velocity structure beneath India and SE Asia from 100 to $1600 \mathrm{~km}$ (from [31]). Six tentative correlations show contours of reconstructed Asian plate boundary position and shape from Fig. 1 (thick dotted lines) superimposed on deep high-wavespeed slab anomaly: $5 \mathrm{Ma}, 200 \mathrm{~km}$; $10 \mathrm{Ma}, 400 \mathrm{~km} ; 15 \mathrm{Ma}, 600 \mathrm{~km}$; $30 \mathrm{Ma}, 900$ $\mathrm{km} ; 40 \mathrm{Ma}, 1100 \mathrm{~km}$; and $50 \mathrm{Ma}(?), 1300 \mathrm{~km}$. 

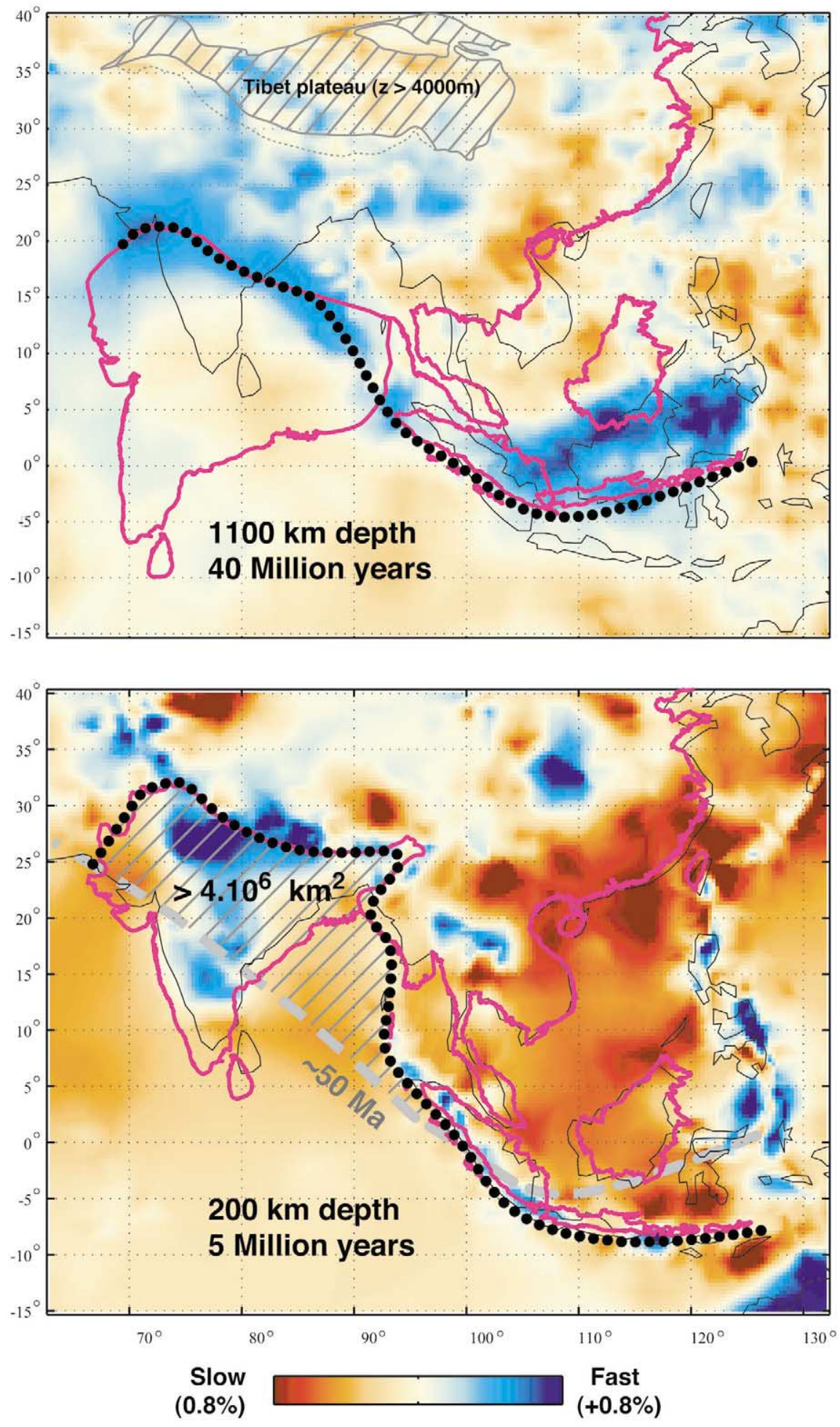
be offset right-laterally by about $1500 \mathrm{~km}$ (Figs. 2 and 4). On the $900 \mathrm{~km}$ depth section (Fig. 2) it seems to be completely interrupted between 10 and $20^{\circ} \mathrm{N}$. East of $105^{\circ} \mathrm{E}$, beneath the present southeastern prong of southeast Asia, the slab anomaly moves southwards and rotates clockwise with decreasing depth, from ENE around $5^{\circ} \mathrm{N}$ at $1100 \mathrm{~km}$ depth to roughly EW between 5 and $10^{\circ} \mathrm{S}$ at $700 \mathrm{~km}$ depth and shallower (Figs. 2 and 4).

These changes in tomographically inferred slab geometry match those of the reconstructed plate boundary position quite well (Figs. 1, 2, 4 and 5). They can be readily interpreted to reflect the profound disruption, under the thrust of collision, of Asia's margin and the correlative deformation of southern regions of continental Asia. The impingement and northward motion of the northeast corner of continental India, roughly along the $95^{\circ} \mathrm{E}$ meridian, probably interrupted oceanic subduction and sheared the slab right-laterally $[15,19]$. The southeastward, clockwise motion of the boundary of SE Asia [26] and of the subducting slab along it [5] likely followed the extrusion of the Sunda blocks along the Wang Chao and Ailao Shan shear zones between 40-45 and 20-15 Ma [13,27]. At a more detailed level, it is possible that the small, initial counterclockwise swing in orientation of the SE Asian slab structure east of $110^{\circ}$, between 1100 and $900 \mathrm{~km}$ depth (Fig. 2e and $\mathrm{f}$ ), reflects the fact that blocks southwest of the Wang Chao zone were pushed southeastward before the rest of Indochina farther north $[27,44]$.

In the mantle above $600 \mathrm{~km}$ the high-wavespeed anomaly surrounding southeast Asia is quite narrow, and its geographical position in the present-day Siberian reference frame moves much less. This is consistent with the nearly sta- tionary position of the convergent margin in the reconstruction (Figs. 1 and $2 \mathrm{a}-\mathrm{c}$ ). A significant change, however, occurs along the roughly north-south-trending stretch of the western boundary of SE Asia, near $95^{\circ} \mathrm{E}$. From the tomograms in Figs. 2 and 4, we infer that a high-wavespeed anomaly grows, mostly northwards, looking upwards from 700 to $400 \mathrm{~km}$ depth. On section IV (Fig. 3) this steeply east-dipping anomaly is separated from that seen deeper down, below the transition zone. The most straightforward interpretation is that oceanic subduction resumed after the passage of the NE corner of the Indian continent (including the Shillong block) and propagated northwards along the transpressional boundary south of it. At $400 \mathrm{~km}$ depth this new subduction is seen to form a continuous zone all the way to Assam (Figs. 2b-d and 4). Its development was likely a consequence of oblique convergence along the Andaman segment of the India/ Asia plate boundary between 20 and $10 \mathrm{Ma}$ and of the growing expanse of oceanic lithosphere (Gulf of Bengal) in the wake of India's NE prong.

West of $90^{\circ} \mathrm{E}$, the depth-integrated evolution of mantle structure beneath India also yields insight into the dynamics of the frontal part of the collision zone. In map view, the apparent northward shift, from $\approx 15$ to $\approx 28^{\circ} \mathrm{N}$, with decreasing depth between 1000 and $400 \mathrm{~km}$, of the highwavespeed anomaly (Figs. 2 and 4) confirms that the Indian subcontinent overrode its own overturned, downwelling lithospheric mantle, as pointed out by Van der Voo and coworkers [6]. That this actually occurred is especially clear in the two tomographic sections perpendicular to the central part of the Himalayas (II, III, Fig. 3). Two important observations can be made from these new sections, which look remarkably similar, though more than $500 \mathrm{~km}$ apart. First, beneath

Fig. 5. More detailed view of matches between tomograms at 200 and $1100 \mathrm{~km}$, and reconstructions of SE Asia at 5 and $40 \mathrm{Ma}$ (extracted from Fig. 1), respectively. Both diagrams are shown in present-day Asia reference frame (thin lines and Lat.-Long. coordinates). Thick black dotted lines represent corresponding positions of India/Asia plate boundary inferred from retro-deformed continental contours (magenta lines). Thick dashed gray line on $200 \mathrm{~km}$ depth tomogram is southern limit of $1300 \mathrm{~km}$ deep (50 Ma?) high-wavespeed anomaly from Fig. 4. Hatched area between 5 and 50 Ma boundaries represents minimum surface ( $>4$ million $\mathrm{km}^{2}$ ), absorbed by deformation of Asia north of the Zangbo suture. Present positions of Tibet-Pamir plateau (area with elevation above $4000 \mathrm{~m}$, hatched) and of southern limit of Himalayan range (MFT, thin dotted line) are also shown on $1100 \mathrm{~km}$ depth tomogram. 
the Himalayas, the Precambrian lithospheric mantle of India sinks steeply down to the transition zone. Second, deeper down, the corresponding high-wavespeed anomaly continues with a southward dip over a horizontal distance of $\approx 1500 \mathrm{~km}$ to approximately $1000 \mathrm{~km}$ depth, below which it appears to sink almost vertically to a depth of about $2000 \mathrm{~km}$ (Fig. 3). This geometry is particularly clear for the high-wavespeed anomaly's southern limit, which is rather continuous and linear (and outlined on Fig. 3), while below the transition zone, the bottom part of this anomaly appears to spread out into subzones that have been inferred previously to represent distinct Tethyan slabs [6]. We interpret the relatively shallow south-dipping part of the S-shaped, southern contour of the anomaly to reflect the northwards sweep of the active margin of Asia, by impinging India, after collision began. Conversely, the steeply dipping deeper portion would correspond to subduction of oceanic lithosphere under the steady Asian margin before collision, as observed in map view in Fig. 4. The knickpoint at about $1000 \mathrm{~km}$ depth in both sections would thus mark the onset of continental collision. If correct, such inferences would imply that collision occurred about 50 million years ago, if one took the Quaternary rate of Himalayan underthrusting $(\approx 2$ $\mathrm{cm} / \mathrm{yr}$ ) (e.g., [45]) to be representative of the average sinking rate of India's lithospheric mantle. The $1500 \mathrm{~km}$ northward drag of the Asian margin would confirm, in keeping with paleomagnetic studies, that Asian deformation north of the Zangbo suture absorbed over half of the total India/Asia convergence since that time, particularly in the early phases of collision, in keeping with the minimum surface $\left(\approx 4\right.$ million $\left.\mathrm{km}^{2}\right)$ displaced by the indentation of Asia (hatched area on Fig. 5). This in turn would be consistent with the extrusion of Sundaland, prior to $15 \mathrm{Ma}$, and with the build-up of the Tibet plateau at the expense of Asian, not Indian, lithosphere. That the high-wavespeed mantle anomaly barely extends north of the Zangbo suture (Fig. 3) would further support the latter inference and, therefore, growth models of Tibet invoking thickening of Asian crust only (e.g., [46]). Whatever deep high-wavespeed anomaly might be found above $1000 \mathrm{~km}$ depth beneath the Tibet plateau proper would thus likely result from continental subduction of Asian mantle (e.g., [9]) rather than of Indian mantle, as advocated by Tillman et al. [47] on the basis of a south-dipping high P-wave velocity zone found approximately beneath the Bangong suture along the Indepth III profile.

\section{Conclusion}

The first-order match we find between reconstructed surface block motions and mantle structure beneath India and SE Asia, two completely independent sets of results, provides further support for the link between plate boundary movement and convective flow across the transition zone into the lower mantle. The 4-D evolution documented here suggests that the deformation episode that reorganized southeast Asia between 40 and $15 \mathrm{Ma}$ - with $\sim 700 \mathrm{~km}$ of extrusion of Indochina, stretching of the Sunda shelf, and $\sim 550 \mathrm{~km}$ of seafloor spreading in the South China Sea - is reflected by the large shifts in slab geometry between 1100 and $700 \mathrm{~km}$ depth (Figs. 2, 4 and 5). This, in view of the age constraints consistent with surface tectonics, implies that in this region, sinking of cold lithosphere, apparently with little lateral advection in a mantle reference frame, took place at rates of $\sim 2 \mathrm{~cm} / \mathrm{yr}$ below 700 $\mathrm{km}$, as inferred elsewhere [6,32,33], and of $\sim 5$ $\mathrm{cm} / \mathrm{yr}$ above $700 \mathrm{~km}$. Preliminary geophysical flow modeling based on Stokes' law suggests that, with the above timing, the observed slab morphology is best explained by a lower to upper mantle viscosity ratio of 200 [31,48]. The reappearance of a short, narrow sinking slab above $600 \mathrm{~km}$ on the west side of SE Asia may reflect the birth and along-strike northwards growth of a new subduction zone. The matching in map view (Figs. 4 and 5), as well as the shape and southward dip of the high-wavespeed anomaly in the mantle beneath India (Fig. 3), constrain the age of collision onset to be between 40 and $55 \mathrm{Ma}$, the maximum extent of greater India north of the MFT to be less than $1000 \mathrm{~km}$, and the amount of convergence absorbed by deformation of Asia to be at least $1500 \mathrm{~km}$. Equally important, it 
probably yields additional clues on the formation of Tibet. While at the edge of current resolution, the images suggest that the Indian lithosphere kept plunging mostly south of the present position of the Indus-Zangbo suture, hence that models invoking underthrusting of greater India (crust or mantle) towards the north much beyond this suture (e.g., beneath all of Tibet $[49,50]$; or all the way to the Bangong suture [47]) ought to be reconsidered. Finer resolution tomography, a better understanding of lower mantle viscosity and flow time constants, and improvements in reconstructing surface deformations will be needed to constrain with greater accuracy both the onset of India's impact, the size of greater India, and possible irregularities (e.g., slab breakoff [51]) in the subduction of continental lithospheric mantle.

\section{Acknowledgements}

This work was supported in part by programs IT and DYETI of INSU (Institut National des Sciences de l'Univers), and by recurrent funds allotted to UMR 7578 of CNRS (Centre National de la Recherche Scientifique, Paris). R.D.v.d.H. acknowledges support from IPGP as a Visiting Professor. The tomography model was constructed under NSF grant EAR 9909492. We thank C. Lithgow-Bertelloni and J.P. Gratier for constructive comments that helped improve and clarify the original manuscript. Anne Claire Morillon is responsible for the quality of the figures. This is IPGP contribution no. IPGP 1973.[VC]

\section{References}

[1] W. Spakman, S. Van der Lee, R.D. Van der Hilst, Traveltime tomography of the European-Mediterranean mantle down to 1400 km, Phys. Earth Planet. Inter. 79 (1993) 3-74.

[2] C. Piromello, A. Morelli, P-wave tomography of the mantle under the Alpine-Mediterranean area, J. Geophys. Res. 108 (2003) 2065.

[3] R.D. Van der Hilst, E.R. Engdahl, W. Spakman, G. Nolet, Tomographic imaging of subducted lithosphere below northwest Pacific island arcs, Nature 353 (1991) 37-42.

[4] Y. Fukao, M. Obayashi, H. Inoue, N. Nenbai, Subduct- ing slabs stagnant in the mantle transition zone, J. Geophys. Res. 97 (1992) 4822-4909.

[5] S. Widiyantoro, R.D. Van der Hilst, Structure and evolution of subducted lithosphere beneath the Sunda arc, Indonesia, Science 271 (1996) 1566-1570.

[6] R. Van der Voo, R.H. Bijwaard, W. Spakman et al., Tethyan subducted slabs under India, Earth Planet. Sci. Lett. 171 (1999) 7-20.

[7] G. Peltzer, F. Saucier, Present-day kinematics of Asia derived from geologic fault rates, J. Geophys. Res. 101 (1996) 27943-27956.

[8] S.M. McClusky et al., Global Positioning System constraints on plate kinematics and dynamics in the eastern Mediterranean and Caucasus, J. Geophys. Res. 105 (2000) 5695-5719.

[9] P. Tapponnier, X. Zhiqin, F. Roger, B. Meyer, N. Arnaud, G. Wittlinger, Y. Jingsui, Oblique stepwise rise and growth of the Tibet plateau, Science 294 (2001) 16711677.

[10] J. Vergnes, G. Wittlinger, Q. Hui, P. Tapponnier, G. Poupinet, J. Mei, G. Herquel, A. Paul, Seismic evidence for stepwise thickening of the crusy across the NE Tibetan plateau, Earth Planet. Sci. Lett. 203 (2002) 25-33.

[11] G. Wittlinger, J. Vergne, P. Tapponnier, V. Farra, G. Poupinet, M. Jiang, H. Su and Lithoscope Team, Teleseismic imaging of subducting lithosphere and Moho offsets beneath western Tibet, Earth Planet. Sci. Lett. DOI: 10.1016/j.epsl.2003.12.012, this issue.

[12] G. Wittlinger, P. Tapponnier, G. Poupinet, J. Mei, S. Danian, G. Herquel, F. Masson, Tomographic evidence for localized lithospheric shear along the Altyn Tagh fault, Science 282 (1998) 74-76.

[13] P.H. Leloup, R. Lacassin, P. Tapponnier, U. Schärer, Z. Dalai, L. Xiaohan, Z. Liangshang, J. Shaocheng, P.T. Trinh, The Ailao Shan-Red River shear zone (Yunnan, China), Tertiary transform boundary of Indochina, Tectonophysics 251 (1995) 3-84.

[14] A. Replumaz, R. Lacassin, P. Tapponnier, P. Leloup, Large river offsets and Plio-Quaternary dextral slip rate on the Red River fault (Yunnan, China), J. Geophys. Res. 106 (B1) (2001) 819-836.

[15] G. Peltzer, P. Tapponnier, Formation and evolution of strike-slip faults, rifts, and basins during the India-Asia collision: an experimental approach, J. Geophys. Res. 93 (B12) (1988) 15085-15117.

[16] B.D. Ritts, U. Biffi, Magnitude of post-Middle Jurassic (Bajocian) displacement on the central Altyn Tagh fault system, northwest China, Geol. Soc. Am. Bull. 112 (2000) 61-74.

[17] J. Van der Woerd, P. Tapponnier, F.J. Ryerson, A.S. Meriaux, B. Meyer, Y. Gaudemer, R.C. Finkel, M.W. Caffee, G. Zhao, Z. Xu, Uniform Post-Glacial slip-rate along the central $600 \mathrm{~km}$ of the Kunlun Fault (Tibet), from ${ }^{26} \mathrm{Al},{ }^{10} \mathrm{Be}$, and ${ }^{14} \mathrm{C}$ dating of riser offsets, and climatic origin of the regional morphology, Geophys. J. Int. 148 (2002) 356-388.

[18] C. Lasserre, Y. Gaudemer, P. Tapponnier, A.-S. Meriaux, 
J. Van der Woerd, Y. Daoyang, F.J. Ryerson, R.C. Finkel, M.W. Caffee, Fast late-Pleistocene slip-rate on the Leng Long Ling segment of the Haiyuan fault, Qinghai, China, J. Geophys. Res. 107 (2002) 2276-2291.

[19] A. Replumaz, P. Tapponnier, Reconstruction of the deformed collision zone between Indian and Asia by backward motion of lithospheric blocks, J. Geophys. Res. 108 (2003) DOI: 10.1029/2001JB000661, 2003.

[20] P. Tapponnier, P. Molnar, Active faulting and tectonics of China, J. Geophys. Res. 82 (1977) 2905-2930.

[21] A.Y. Le Dain, P. Tapponnier, P. Molnar, Active faults and tectonics of Burma and surrounding regions, J. Geophys. Res. 89 (1984) 453-472.

[22] R. Armijo, P. Tapponnier, T. Han, Late Cenozoic rightlateral strike-slip faulting in southern Tibet, J. Geophys. Res. 94 (1989) 2787-2838.

[23] G. Peltzer, P. Tapponnier, R. Armijo, Magnitude of late Quaternary left-lateral displacements along the northern edge of Tibet, Science 246 (1989) 1285-1289.

[24] Y. Gaudemer, P. Tapponnier, B. Meyer, G. Peltzer, G. Shunmin, C. Zhitai, D. Huagung, I. Cifuentes, Partitioning of crustal slip between linked, active faults in the eastern Qilian Shan, and evidence for a major seismic gap, the 'Tianzhu gap', on the western Haiyuan fault, gansu (China), Geophys. J. Int. 120 (1995) 599-645.

[25] T.M. Harrison, P.H. Leloup, F.J. Ryerson, P. Tapponier, R. Lacassin, C. Wenji, Diachronous initiation of transtension along the Ailao Shan-Red River Shear zone, Yunnan and Vietnam, in: The Tectonics of Asia, Cambridge University Press, New York, 1996.

[26] A. Briais, Ph. Patriat, P. Tapponnier, Updated interpretation of magnetic anomalies and seafloor spreading stages in the South China Sea, implications for the Tertiary tectonics of SE Asia, J. Geophys. Res. 98 (B4) (1993) 6299-6328.

[27] R. Lacassin, H. Maluski, P.H. Leloup, P. Tapponnier, C. Hinthong, K. Siribhakdi, S. Chuaviroj, A. Charoenravat, Tertiary diachronic extrusion and deformation of western Indochina: structural and ${ }^{40} \mathrm{Ar} /{ }^{39} \mathrm{Ar}$ evidence from NW Thailand, J. Geophys. Res. 102 (1997) 10013-10037.

[28] Z. Yang, J. Besse, Paleomagnetic study of Permian and Mesozoic sedimentary rocks from northern Thailand supports the extrusion model for Indochina, Earth Planet. Sci. Lett. 117 (1993) 525-552.

[29] E.R. Engdahl, R.D. Van Der Hilst, R.P. Buland, Global teleseismic earthquake relocation with improved travel times and procedures for depth determination, Bull. Seism. Soc. Am. 88 (1998) 722-743.

[30] H. Kárason, R.D. Van der Hilst, Tomographic imaging of the lowermost mantle with differential times of refracted and diffracted core phases (PKP, P (sub diff)), J. Geophys. Res. 106 (2001) 6569-6587.

[31] H. Kárason, Thesis, Massachusetts Institute of Technology, Cambridge, MA, 2002.

[32] S.P. Grand, R.D. Van Der Hilst, S. Widiyantoro, Global seismic tomography; a snapshot of convection in the Earth, GSA Today 7 (1997) 1-7.
[33] R.D. Van der Hilst, S. Widiyantoro, E.R. Engdahl, Evidence for deep mantle circulation from global tomography, Nature 386 (1997) 578-584.

[34] J. Trampert, J.H. Woodhouse, High resolution global phase velocity distributions, Geophys. Res. Lett. 23 (1996) 21-24.

[35] G. Ekstrom, A.M. Dziewonski, The unique anisotropy of the Pacific upper mantle, Nature 394 (1998) 168-172.

[36] F.J. Simons, R.D. Van der Hilst, J.-P. Montagner, A. Zielhuis, Multimode Rayleigh wave inversion for heterogeneity and azimuthal anisotropy of the Australian upper mantle, Geophys. J. Int. 151 (2002) 738-755.

[37] V. Courtillot, A. Davaille, J. Besse, J. Stock, Three distinct types of hotspots in the Earth's mantle, Earth Planet. Sci. Lett. 205 (2003) 295-308.

[38] H. Lyon-Caen, P. Molnar, Constraints on the structure of the Himalaya from an analysis of gravity anomalies and a flexural model of the lithosphere, J. Geophys. Res. 88 (1983) 8171-8191.

[39] L. Ratschbacher, W. Frisch, C. Chengshen, P. Guitang, Deformation and motion along the southern margin of the Lhasa Block (Tibet) prior to and during the IndiaAsia collision, J. Geodyn. 16 (1992) 21-54.

[40] J. Besse, V. Courtillot, J.P. Pozzi, M. Westphal, Y.X. Zhou, Palaeomagnetic estimates of crustal shortening in the Himalayan thrusts and Zangbo Suture, Nature 311 (1984) 621-626.

[41] Ph. Patriat, J. Achache, India-Eurasia collision chronology has implications for crustal shortening and driving mechanism of plates, Nature 311 (1984) 615-621.

[42] J. Besse, V. Courtillot, Paleogeographic maps of the continents bordering the Indian Ocean since the Early Jurassic, J. Geophys. Res. 93 (1988) 11791-11808.

[43] J. Achache, V. Courtillot, Z. Yaoxiu, Paleogeographic and tectonic evolution of southern Tibet since Middle Cretaceous time; new paleomagnetic data and synthesis, J. Geophys. Res. 89 (1984) 10311-10339.

[44] P. Tapponnier et al., Propagating extrusion tectonics in Asia: new insights from simple experiments with plasticine, Geology 10 (1982) 611-616.

[45] J. Lavé, J.P. Avouac, Active folding of fluvial terraces across the Siwaliks Hills, Himalayas of central Nepal, J. Geophys. Res. 105 (2000) 5735-5770.

[46] B. Meyer, P. Tapponnier, L. Bourjot, F. Métivier, Y. Gaudemer, G. Peltzer, G. Shunmin, C. Zhitai, Crustal thickening in Gansu-Qinghai, lithospheric mantle subduction, and oblique, strike-slip controlled growth of the Tibet Plateau, Geophys. J. Int. 135 (1998) 1-47.

[47] F. Tillman, J. Ni and INDEPTH III Seismic Team, Seismic imaging of the downwelling Indian lithosphere beneath central Tibet, Science 300 (2003) 1424-1429.

[48] H. Kàrason, R.D. Van der Hilst, B.H. Hager, A. Replumaz, P. Tapponnier, Integrating Seismic Tomography, 3-D Spherical Flow Modeling, and Plate Reconstructions, EGS, Nice, 2002.

[49] M. Barazangi, J. Ni, Velocities and propagation characteristics of $\mathrm{Pn}$ and $\mathrm{Sn}$ beneath the Himalayan Arc and 
Tibetan Plateau; possible evidence for underthrusting of Indian continental lithosphere beneath Tibet, Geology 10 (1982) 179-185.

[50] J. Ni, M. Barazangi, High-frequency seismic wave propagation beneath the Indian Shield, Himalayan Arc, Tibetan Plateau and surrounding regions; high uppermost mantle velocities and efficient $\mathrm{Sn}$ propagation beneath Tibet, Geophys. J. R. Astron. Soc. 72 (1983) 665-689.

[51] S. Guillot, E. Garzanti, D. Baratoux, D. Marquer, G.
Maheo, J. de Sigoyer, Reconstructing the total shortening history of the Northwest Himalayas, Geochem. Geophys. Geosyst. 4 (2003) 484-506.

[52] A.-S. Mériaux, F.J. Ryerson, P. Tapponnier, J. Van der Woerd, R.C. Finkel, Xu Xiwei, Xu Zhiqin, M.W. Caffee, Rapid slip along the central Altyn Tagh Fault: Morphochronologic evidence from Cherchen $\mathrm{He}$ and Sulamu Tagh, J. Geophys. Res. (2004) in press. 